\title{
Network to combat violence against rural women: articulation and communication of services
}

\author{
Rede de enfrentamento à violência contra mulheres rurais: articulação e comunicação dos serviços
}

Red de enfrentamiento a la violencia contra las mujeres rurales: articulación y comunicación de los servicios

\section{Luana Cristina Borth', Marta Cocco da Costa", Ethel Bastos da Silva", Darielli Gindri Resta Fontana", Jaqueline Arboit"}

\author{
' Hospital Municipal Dr Cruzatti. Marechal Cândido Rondon, Paraná, Brazil. \\ "Universidade Federal de Santa Maria. Santa Maria, Rio Grande do Sul, Brazil.
}

\section{How to cite this article:}

Borth LC, Costa MC, Silva EB, Fontana DGR, Arboit J. Network to combat violence against rural women: articulation and communication of services. Rev Bras Enferm [Internet]. 2018;71(Suppl 3):1212-9.

[Thematic Issue: Health of woman and child] DOI: http://dx.doi.org/10.1590/0034-7167-2017-0044

Submission: 02-23-2017 Approval: 06-15-2017

\begin{abstract}
Objective: to identify the constituent services of the network to combat violence against rural women in municipalities in the northwestern region of Rio Grande do Sul and to analyze the articulation and communication of services in search of the resolution of situations of violence. Method: descriptive-exploratory, qualitative study, carried out through semi-structured interviews with 26 professionals from intersectoral services, as well as managers and/or those responsible for these services. Data were systematized through content analysis. Results: although the professionals collectively discuss and plan coping actions, difficulties were identified in the approximation between services, related to the definition of flow, knowledge of actions/referrals, fear of seeing and reporting violence, understanding that it is not a question of demand of their field of action, and women's access to services. Final considerations: it is evident the need to implement public policies that address the singularities of violence against women in rural settings.
\end{abstract}

Descriptors: Violence; Violence Against Women; Women's Health; Health of the Rural Population; Confrontation.

\section{RESUMO}

Objetivo: identificar os serviços constituintes da rede de enfrentamento à violência contra mulheres rurais em municípios da região noroeste do Rio Grande do Sul e analisar a articulação e a comunicação dos serviços na busca da resolutividade das situações de violência. Método: estudo descritivo-exploratório, qualitativo, realizado por meio de entrevistas semiestruturadas com 26 profissionais de serviços intersetoriais, além de gestores e/ou responsáveis por estes serviços. Os dados foram sistematizados mediante a análise de conteúdo. Resultados: embora os profissionais discutam e planejem coletivamente as ações de enfrentamento, identificaram-se dificuldades na aproximação entre os serviços, relacionadas à definição de fluxo, conhecimento das ações/ encaminhamentos, medo de ver e notificar a violência, entendimento de que não se trata de uma demanda do seu campo de atuação, e o próprio acesso das mulheres aos serviços. Considerações finais: evidencia-se a necessidade de implementação de políticas públicas que atendam as singularidades da violência contra as mulheres no cenário rural.

Descritores: Violência; Violência Contra a Mulher; Saúde da Mulher; Saúde da População Rural; Enfrentamento.

\section{RESUMEN}

Objetivo: identificar los servicios constituyentes de la red de enfrentamiento a la violencia contra mujeres rurales en municipios de la región noroeste de Rio Grande do Sul y analizar la articulación y la comunicación de los servicios en la búsqueda de la resolutividad de las situaciones de violencia. Método: estudio descriptivo-exploratorio, cualitativo, realizado por medio de entrevistas semiestructuradas con 26 profesionales de servicios intersectoriales, además de gestores y/o responsables de estos servicios. Los datos se sistematizaron mediante el análisis de contenido. Resultados: aunque los profesionales discuten y planifican colectivamente las acciones de enfrentamiento, se identificaron dificultades en la aproximación entre los servicios, relacionadas a la definición de flujo, conocimiento de las acciones/encaminamientos, miedo de ver y notificar la violencia, entendimiento de que no se trata de una demanda de su campo 
de actuación, y el propio acceso de las mujeres a los servicios. Consideraciones finales: se evidencia la necesidad de implementación de políticas públicas que atiendan las singularidades de la violencia contra las mujeres en el escenario rural.

Descriptores: Violencia; Violencia contra la Mujer; Salud de la Mujer; Salud de la Población Rural; Enfrentamiento.

\section{CORRESPONDING AUTHOR Jaqueline Arboit E-mail: jaqueline.arboit@hotmail.com}

\section{INTRODUCTION}

Violence against women is prevalent throughout the world and is internationally recognized as a social and public health problem $^{(1-2)}$. The concept of violence against women employed in this study is consistent with the National Policy on Combating Violence against Women, which defines it as any gender-based action or omission that causes them death, injury, psychological, sexual or psychological distress and moral or property damage in the public or private sphere ${ }^{(3)}$.

Data from the ten-year balance sheet of the Women's Assistance Center - Call 180 indicate that in Brazil, from its creation in 2005 to $2015,4,708,978$ appointments were made. As to the forms of violence perpetrated against women, this balance revealed that physics represents more than half of the reports of violence $(56.72 \%)$, followed by psychological $(27.14 \%)$, moral $(10.16 \%)$ and $(2.32 \%)^{(4)}$.

This problem affects women in different settings, one of which is rural. There is an effort by researchers to make visible the specific problems that rurality imposes on women in situations of violence. In this sense, women are continuously exposed to different types of violence, ranging from physical, psychological, moral, sexual, to work overload and deprivation of liberty on the part of the husband and/or partner ${ }^{(5)}$.

In addition, violence against women tends to worsen in rural areas, since they are often overlooked ${ }^{(6)}$, given the geographical distance from the urban $\operatorname{area}^{(7)}$. Thus, isolation increases the chances of these women experiencing violence ${ }^{(8)}$.

Against this background, it is evident that rural women in situations of violence face numerous challenges that are manifested by the inequality of access to public services, the labor market and land tenure, which reflects in inequalities in living conditions and health ${ }^{(9-10)}$. The study also reveals that municipal managers, services and health professionals find it difficult to identify and accommodate the demands and needs of rural women and rural workers ${ }^{(11)}$.

In view of the particularities of violence against women and their aggravations in rural settings, their prevention and confrontation require the interlocution of various sectors of society ${ }^{(1)}$, which is within the framework of the network to combat violence against women. This concerns the articulated action between governmental/non-governmental institutions/services and the community, aiming at the development of effective prevention strategies and policies that guarantee the empowerment and the construction of women's autonomy, their human rights, the accountability of aggressors and qualified assistance to women in situations of violence ${ }^{(12)}$.

Considering the importance of the network to combat violence against women, the scarce scientific production on violence against women in this scenario and the possibility of giving greater visibility to this problem, it is intended to answer the following guiding questions: Which are the constituent services of the network against violence against rural women in municipalities in the northwestern region of Rio Grande do Sul? How do the articulation and communication between these services take place?

\section{OBJECTIVE}

To identify the constituent services of the network to combat violence against rural women in municipalities in the northwestern region of Rio Grande do Sul and to analyze the articulation and communication of services in search of the resolution of situations of violence.

\section{METHOD}

\section{Ethical aspects}

This study complied with the norms of Resolution 466/2012 of the National Health Council(13). The same was appreciated and approved by the Human Research Ethics Committee (HRECs) of the Universidade Federal do Rio Grande do Sul (UFRGS). Before the data collection procedure, the participants were clarified individually through the Free and Informed Consent Form about the objectives of the research, having been signed in two ways by all participants, staying one way with these and the other with the researcher.

\section{Theoretical and methodological reference}

\section{Type of study}

The present study is descriptive with a qualitative approach. The qualitative approach applies to the study of history, relationships, representations, perceptions and opinions, resulting from humans' view of themselves, their ways of living and constructing their artifacts, as well as their feelings and thoughts ${ }^{(14)}$.

The theoretical framework was based on references on the network to combat violence against women, already mentioned in the introduction.

\section{Methodological procedures}

\section{Study scenario}

The study was developed in four municipalities located in the northwest region of the state of Rio Grande do Sul. The choice of two of them is due to the fact that they are medium-sized and have medium complexity service reference poles. The others were listed as having a small and larger population in the rural scenario compared to the urban one. It should be noted that the four municipalities have their economy based on family agriculture and the presence of few owners of large territorial 
extensions. In the municipalities of this study, the only sector that has services located in the rural context is the health sector, which has Family Health Strategy Units; the other intersectoral services are found in the urban context of these municipalities.

\section{Data source}

The participants were professionals from intersectoral services, as well as managers and/or those responsible for these services, who make up the network to deal with situations of violence against women in the municipalities of the research scenario. As inclusion criterion was adopted: to be professional, manager and/or responsible for one of the services for more than six months. The exclusion criterion included: being absent from work by license of any nature (pregnant, sick, adoptive) during the period of data collection.

\section{Collection and data organization}

After contact with the coordination of the services, a list of the possible participants of the study was constituted. The study included 26 professionals, managers and/or service providers of the coping network, 18 (69\%) women and eight (31\%) men, using the inclusion and exclusion criteria. Participants worked in the agriculture sector - Secretary of Agriculture (7); of health - Municipal Health Department (5); of the police sector - Civilian Police Station (5); of social assistance - Social Assistance Reference Center/Specialized Reference Center for Social Assistance (5) and Municipal Council of Women (1); and education - Municipal Secretary of Education (3). They served as Regional Health Coordinator, General Homicide Coordinator, Secretary of Health, Delegate, police clerk, social worker, psychologist, Secretary of Agriculture and Secretary of Education.

Thus, the production of the data began, which occurred through semi-structured interviews. These were previously scheduled according to the availability of each of the participants, and held individually in a room of the service itself, reserved for the collection of data in order to ensure your privacy. It is noteworthy that the interviews lasted on average 45 minutes, being recorded in MP3. Data collection took place from December 2013 to June 2014.

For the semi-structured interview, a guidebook was developed based on problem-questions related to the object of study, related to the understanding about the network to combat violence against rural women, the services that are part of this network and its articulation.

The empirical cut-off was based on the thematic saturation criterion, used to determine or close the final sample size of a study, interrupting the inclusion of new participants when the data collected becomes redundant or repetitive in the researcher's evaluation ${ }^{(15)}$

\section{Data analysis}

For the systematization and analysis of the data, we used the Content Analysis proposed by Bardin, which is organized in three phases: pre-analysis, material exploration and treatment of results, inference and interpretation ${ }^{(16)}$.

The interviews were transcribed in full in a text editor, in view of the constitution of the corpus of the research. The first phase, pre-analysis, is the organization of the material to be analyzed $^{(16)}$. In this step the listening of the recordings and floating reading of the corpus is carried out, which is the first contact with the transcribed material from the data collection.

In the material exploration phase, the text of the interviews was cut into registration units, which are words, sentences, comparable paragraphs and with the same semantic content, that is, that give meaning to the content of the speeches and subsidize the constitution of the categories initials ${ }^{(16)}$. These units were grouped according to similarities of meaning and were given the unit of thematic content. Following, the registration units were reread, emerging three empirical categories: Approaching the professionals' conceptions regarding the network to combat violence against rural women; the network to address violence against rural women: recognizing services; Approaches between services in the network to combat violence against rural women.

In the third phase, treatment of results, inference and interpretation, the researcher proposes inferences and interpretations about the results, returning to the research objective ${ }^{(16)}$.

In order to guarantee the anonymity of the participants, they were identified by the initials of the services in which they worked, followed by an ordinal number according to the sequence of the interviews: SA - Secretary of Agriculture, MCW - Municipal Council of Women, SARC - Social Assistance Reference Center/Specialized Reference Center for Social Assistance, MED - Municipal Education Department, CPS - Civilian Police Station and MHD - Municipal Health Department.

\section{RESULTS}

\section{Approaching the professionals' conceptions regarding the network for coping with violence}

It is identified that some professionals conceived the network as a work developed by different professionals within the same team. They also mentioned how the joint action with services of other sectors, which are added in the constitution of the network.

Networking is working together, not just one area. (SARC13)

The team has to be together, we have to make the network [...] because it has to do all the research, all the treatment, it has to work together. (MHD26)

For us, working in a network is working in an articulated service to others. (SA10)

Regarding the arrangement of the services of the coping network, the participants mentioned the need to define the actions/functions to be developed by each professional and service when attending rural women in situations of violence.

[Network] must be well designed, with well-knotted nodes and in which the function of each one needs to be clear, the responsibility ... so that [woman] can trust these services. (SA8)

It is a network of professionals ready for service in cases where it is necessary to perform. (CPS20) 
The network would be composed of several segments of society, capable of providing assistance to the victims regarding their rights. (CPS22)

\section{Recognizing the network's services to combat violence}

Among the public services constituent of the coping network in the municipalities scenario of the study, the participants cited police, social assistance, health, education and justice. They also emphasized the importance of the action of the whole society to confront the problem of violence against rural women.

Police station, social assistance, health. (MHD10)

There is SARC [Social Assistance Reference Center], SRCSA [Specialized Reference Center for Social Assistance] that go after these issues [...] we try to work consistently in order to minimize suffering. (MED25)

It starts with SARC [Social Assistance Reference Center], and we're going ... we work a lot with health, social assistance, education, the Public Prosecutor's Office, and the judiciary. So this is our network. (SARC21)

It does not have as a single entity to cover this entire situation, so it has all the involvement, including of the society. (CPS12)

The professionals also mentioned the involvement of two other services: the Technical Assistance and Rural Extension Company (Emater) and the Municipal Secretary of Agriculture. These, according to the interviewees, are the sectors that are closest to women in the rural context.

We join the entire network, we ask for all bodies, including Emater [Technical Assistance and Rural Extension Company], education, health, agriculture [...] agriculture is there in the settler's house. (MHD26)

Another component of the coping network referred to by one of the professionals is the Municipal Council of Women.

There is a very big partnership between all the entities that make up the Municipal Council of Women. (MCW9)

\section{Approaches between services in the network to deal with violence}

The following testimonies reveal that the services sought to act in a shared way, through dialogue, planning and definition of actions for each service.

We sit and talk, plan, such a service does such a thing and the other does such an action [...] what measures each one can take. (SARC13)

When we see that it is a case that is in all organs of the network, that person or family is circulating in all organs, both education and health, SRCSA [Specialized Reference Center for Social Assistance], Guardianship Council, we gather the team and make the discussion of the case [...] what will be sent, where is going to be forwarded, what professional will attend. (SARC21)
Before defining the actions and referrals needed to meet the demands of rural women in situations of violence, one of the professionals revealed that she sought to accommodate these women.

When it comes to me, I make the first welcome ... if I see that there is a very complicated case, then I discuss it with my coordinator, we talk, socialize the information. (SARC21)

In the testimonies, professionals also pointed out some difficulties faced to act in the network of confrontation, such as the lack of definition of an organized flow, which may harm the professionals' performance and the confrontation of this problem.

When I identify [the situation of violence], what do I really do? Where does this woman go? How do we follow up on this? (SA8)

Another reported difficulty relates to the fear of attending to and reporting situations of violence against rural women. Although the problem is perceived as demand by some professionals, it is denied by others.

We're afraid to see, that's why we do not see it. (SA8)

The professionals are afraid to work, are afraid to notify, as if the service was not a problem for all of us, workers, all of us citizens. (MHD26)

There were among the professionals in the study those who recognized violence against rural women as a problem that deserves attention, but cited the lack of preparation of professionals as a condition that hinders the reception of women and, consequently, other referrals that would be necessary.

From the moment that there was an aggression, we need to treat, and there must be a team, but the professionals are not prepared to respond to violence, to make the welcome. (MHD26)

One of the professionals also reported the difficulty of rural women in reaching the network services, due to the lack of means of transportation to the urban context where these services are concentrated.

Her access [woman] to public agencies that could give her assistance is also restricted by her difficulty in getting to the city [urban environment]. (CPS22)

\section{DISCUSSION}

For the professionals interviewed, the network design for coping with violence against rural women presupposes work within the multiprofessional team and, in this respect, a study indicates the union of knowledges and actions of distinct specialties as the possibility of constructing a coherent care plan with the needs of women $^{(17)}$. This notion finds resonance in the policy of coping with violence, which includes rural women.

The study participants understood the coping network as a "joint" work, starting from the involvement of different sectors that compose it. This conception refers to a model of action in 
which there is a relationship of coexistence between the professionals of the constituent services of the network, communication and proximity are the basis for the practices, resulting in the articulation of services, an essential condition for attention to this problem of a multidimensional nature ${ }^{(12)}$. In this sense, this study reveals that the realities of rural services still require a plural view ${ }^{(7)}$, reflecting the need for a remodeling of care practices.

In this direction, the interviewees pointed out the need to know the services, functions and responsibilities of each professional, because in this scenario many are unaware of the existing services. Corroborating this finding, studies point out that this weakens the articulation of networking, resulting in precarious attention to women ${ }^{(18-19)}$.

In this way, institutions need to be clear about what their objectives are and to pass them on to professionals, guiding, supervising and facilitating the fulfillment of these objectives. There is also a need for reciprocal recognition among the various sectors, in their specificities and in what they have in common as part of this network ${ }^{(20)}$.

Having said this, it is reinforced that the process of interaction between the different sectors that make up the network will only materialize through obtaining mutual knowledge, which involves information about their competencies, attributions, location, internal and external procedures and working hours, for example ${ }^{(21-22)}$.

From this perspective, it is believed that the network of confrontation permeated by interdisciplinarity and the intersectoriality in the rural context would allow an extended view of women. However, it is known that this reality is distant, due to the absence of public policies, the concentration of services that exist in the majority in the urban context, and due to the precariousness in aspects already mentioned. Also, the professionals working in the services face communication difficulties in the team, between the team and the women and between the different services of the coping network. It adds to this list of challenges the geographical distance, the low availability of collective and own/individual transport and communication network, which limits the access of these women, resulting in little resolution attention.

It is reiterated that the potential of the work in the domain of the coping network is related to the quality of the connections and communications between professionals and services, with the knowledge of the sectors involved, commitment, responsibility and attitude of the professionals, aiming at the performance collective and shared.

According to the professionals interviewed, the network to combat violence against rural women is composed of police, justice, social assistance and health, services traditionally more available to women in the urban setting.

This study reveals that the police and the justice sector are historically responsible for dealing with this problem; however, over time and due to the complexity of this problem, the need to include other sectors has been identified ${ }^{(23)}$. However, an international study carried out in a rural setting revealed that the police and judiciary sectors still have great relevance in confronting violence in this scenario ${ }^{(24)}$. This view reinforces the idea that this problem belongs to these sectors, and perhaps there are no others available. However, the importance of the others to make up the coping network is emphasized.

When the professionals mentioned the social assistance, represented here by the Social Assistance Reference Center (SARC) and the Specialized Reference Center for Social Assistance (SRCSA), the importance of this sector to support women is reinforced. However, the priority actions of this sector occur in the urban context, and the rural populations are almost always deserted, although in many municipalities the rural population is $\operatorname{larger}^{(7)}$.

Regarding the health sector, this has been pointed out by other studies as fundamental to the multi- and intersectoral response to violence against women, identifying and intervening from empathic listening, psychosocial support and referrals to other services ${ }^{(24-25)}$.

The education sector was also cited as an integral part of the coping network by study participants. In this sense, the actions of this sector are almost always preventive, with educational interventions in schools, through technical information and also reflections on more supportive, respectful and less prejudiced positions regarding aspects of gender behavior, which includes women and men ${ }^{(24)}$.

Another two services that are part of the coping network mentioned by professionals are the Municipal Secretary of Agriculture and Emater, municipal services that develop specific programs for women related to productive work, whose objective is to encourage daily work with financial and technical assistance and, empowering better conditions of survival and, consequently, greater autonomy, which may make them more prepared to face violence. This study indicates that many rural women are financially dependent on their husbands and / or companions because of the low level of schooling, which competes for the subjugation of these women, who are forced to remain in a violent relationship ${ }^{(5)}$. Thus, the activities of the aforementioned services can promote the autonomy of rural women through work.

The Municipal Council of Women also makes up the coping network, although it was mentioned by only one of the participants. This body, although not directly involved in providing assistance to women experiencing situations of violence, plays a fundamental role in preventing this phenomenon and ensuring the rights of women and, therefore, is listed in the list of members of this network ${ }^{(12)}$.

Study professionals reported that they organized actions based on the coping network plan. In thinking, discussing and collectively planning such actions, professionals have demonstrated a commitment to resolving the situation of violence experienced by rural women, but this is not enough to guarantee their effectiveness. This study shows that, for the actual configuration of a network, the services need to share the assistance ${ }^{(20)}$. However, there are difficulties in the constitution process related to the union and articulation of different health care sectors ${ }^{(26)}$.

The host is indicated as a moment of care that precedes the other actions and referrals within the coping network. During the reception, the professional can hear the report of the situation of violence experienced by the woman and identify the problems, assuming the responsibility to intervene ${ }^{(27)}$. In addition, at this point the professional has the opportunity to share 
information about the available coping network services so that the woman knows them and can decide which ones will be the most important for her at the moment ${ }^{(26)}$.

Among the difficulties for working in the coping network is the lack of knowledge about the actions/referrals to be carried out after the identification of situations of violence. The fact that the professional of the service used by the women as a gateway does not know how to proceed tends to undermine the process of coping with violence. In this sense, a study shows that referrals do not always result in adequate responses to the demands of women who experience violence ${ }^{(18)}$.

The knowledge of the services by the professionals supports the development of actions with a view to prevention, notification, referral and follow-up of women in situations of violence, thus promoting continuity of care and increasing the effectiveness of the service ${ }^{(21)}$.

Some statements express that the professionals admitted to being afraid to see and to notify the situations of violence experienced by the rural women. This behavior may be related to the fear of reprisals by the aggressor, the rural context itself, in which many situations of violence are socially accepted, as well as unpreparedness in the face of a complex problem. This research reinforces that for many professionals the phenomenon of violence "does not exist", that is, it does not make up the object of its intervention practices ${ }^{(7)}$. Thus, if on the one hand they support women to leave the situation of violence, on the other they silence and deny the existence of the problem ${ }^{(28)}$.

The territorial distance of State resources and apparatuses and non-governmental organizations that could protect rural women from exposure to violence and at the same time give them access to study and vocational training is perhaps the most important specificity of this context.

The distancing cited makes rural women more fragile than those who live in the places where services are located. Added to this is family organization in the rural context, where the wife cares for the family, household, children and small animals, such as chickens and pigs, her work being characterized as reproductive and contributory family income, which is administered by man, whose work is called productive. These conditions make the rural woman more submissive to the man and strongly vulnerable to experiencing situations of violence.

In this sense, it is necessary to review and implement public coping policies that contemplate the specificities of rural contexts. One proposal would be to create intersectoral service centers in this scenario, using as a base the existing structures.

\section{Study limitations}

This research presents limitations characteristic of descriptive qualitative studies, especially with regard to the investigation of the reality of municipalities in a single region of the interior of Rio Grande do Sul, which makes it difficult to generalize the results. Thus, it is recommended the development of studies with an intervention approach, with a view to proposing strategies for coping with situations of violence against women living in rural areas.

\section{Contributions to Nursing}

The research presents contributions to the area of Nursing, by giving visibility to a complex and multidimensional phenomenon that deals with violence against rural women in the perspective of the coping network. The study provides support to the professionals involved in this confrontation, especially to the nurse, as a member of this network and the fact that it is present and close to the women living in this territory, through individual and collective actions carried out with the Family Health Strategy. In addition, this study, by pointing out how the articulation and communication of services in the search for the resolution of situations of violence, enables professionals to reflect on their practices and to elaborate intervention strategies to overcome the difficulties presented in this process.

\section{FINAL CONSIDERATIONS}

The results show that in the municipalities scenario of this study, the network to combat violence against rural women is composed of the following sectors and services: police, justice, health, education, SARC, SRCSA, Emater, Municipal Secretary of Agriculture, and Municipal Council of Women.

Although professionals discuss and collectively plan coping actions through intersectoral communication, it has been identified that there are difficulties in approaching service professionals. These difficulties range from the lack of definition of an organized flow, lack of knowledge about the actions/ referrals to be carried out after the identification of the situations of violence, fear of seeing and notifying these situations or by understanding that this is not a demand of their field of professional activity, to the difficulty of rural women access to services. Thus, the results of the study show the need to implement public policies that address the singularities of the problem in the rural scenario and strategies for integration between the sectors and services that constitute the coping network.

\section{FUNDING}

To the National Council of Scientific and Technological Development (CNPq) for the financing of the project "Situational analysis of violence against rural women and the intersectoral interfaces: the problematic in municipalities of the South of Brazil", of which the screen survey forms part.

\section{REFERENCES}

1. García-Moreno C, Zimmerman C, Morris-Gehring A, Heise L, Amin A, Abrahams N, et al. Addressing violence against women: a call to action. Lancet [Internet]. 2015 [cited 2017 Jan 12];385:1685-95. Available from: http://linkinghub.elsevier.com/retrieve/ pii/S0140-6736(14)61830-4 
2. Tetikcok R, Ozer E, Cakir L, Enginyurt O, Iscanli MD, Çankaya S, et al. Violence towards women is a public health problem. J Forensic Leg Med [Internet]. 2016 [cited 2016 Dec 20];44:150-57. Available from: http://www.jflmjournal.org/article/ S1752-928X(16)30131-7/pdf

3. Brasil. Presidência da República. Secretaria Nacional de Enfrentamento à Violência contra as Mulheres. Política Nacional de Enfrentamento à Violência Contra as Mulheres [Internet]. Brasília; 2011 [cited 2016 Dec 10]. Available from: http://www.spm.gov. br/sobre/publicacoes/publicacoes/2011/politica-nacional

4. Brasil. Secretaria de Políticas para as Mulheres. Balanço Ligue 180: uma década de conquistas. [Internet]. Brasília; 2015 [cited 2016 Nov 24]. Available from: http://www.spm.gov.br/central-de-conteudos/publicacoes/publicacoes/2015/balanco180-10meses-1.pdf

5. Arboit J, Costa MC, Hirt MC, Padoin SMM, Colomé ICS, Soares JSF. Domestic violence against rural women: gender interface in community health agents' conception. Ciênc Cuid Saúde[Internet]. 2015 [cited 2016 Nov 24];14(2):1067-74. Available from: http://www.periodicos.uem.br/ojs/index.php/CiencCuidSaude/article/view/23650/pdf_366

6. Sandberg L. Backward, dumb, and violent hillbillies? rural geographies and intersectional studies on intimate partner violence. J Women Soc Work [Internet]. 2013 [cited 2016 Dec 10];28(4):350-65. Available from: http://journals.sagepub.com/doi/ pdf/10.1177/0886109913504153

7. Costa MC, Lopes MJM, Soares JSF. Public health agendas addressing violence against rural women: an analysis of local level health services in the State of Rio Grande do Sul, Brazil. Ciênc Saúde Colet[Internet]. 2015 [cited 2016 Nov 30];20(5):1379-87. Available from: http://www.scielo.br/pdf/csc/v20n5/1413-8123-csc-20-05-01379.pdf

8. Peek-Asa C, Wallis A, Harland K, Beyer K, Dickey P, Saftlas A. Rural disparity in domestic violence prevalence and access to resources. J Women's Health [Internet]. 2011 [cited 2017 Feb 07];20(11):1743-49. Available from: https://www.ncbi.nlm.nih.gov/ pmc/articles/PMC3216064/pdf/jwh.2011.2891.pdf

9. Bonfim EG, Costa MC, Lopes MJM. Vulnerabilidade das mulheres à violência e danos à saúde na perspectiva dos movimentos sociais. Athenea Dig[Internet]. 2013 [cited 2017 Jan 04];13(2):193-205. Available from: http://www.redalyc.org/articulo. oa? id $=53728035012$

10. Edwards KM. Intimate partner violence and the rural-urbansuburban divide myth or reality? a critical review of the literature. Trauma Viol Abuse [Internet]. 2015 [cited 2017 Jan 14];16(3):359-73. Available from: http://journals.sagepub.com/doi/ pdf/10.1177/1524838014557289

11. Costa MC, Lopes MJM, Soares JSF. Violence against rural women: gender and health actions. Esc Anna Nery Rev Enferm[Internet]. 2015 [cited 2016 Dec 19];19(1):163-8. Available from: http://www.scielo.br/pdf/ean/v19n1/en_1414-8145-ean-19-01-0162.pdf

12. Brasil. Secretaria de Políticas Públicas para as Mulheres. Rede de enfrentamento à violência contra as mulheres. [Internet]. Brasília; 2011 [cited 2016 Nov 22]. Available from: http://www.spm.gov.br/sobre/publicacoes/publicacoes/2011/rede-de-enfrentamento

13. Brasil. Ministério da Saúde. Conselho Nacional de Saúde. Resolução, n.466/2012 - Normas para pesquisa envolvendo seres humanos [Internet]. Brasília; 2012 [cited 2016 Dec 01]. Available from: http://conselho.saude.gov.br/web_comissoes/conep/ aquivos/resolucoes/23_out_versao_final_196_ENCEP2012.pdf

14. Minayo MCS. O Desafio do Conhecimento: pesquisa qualitativa em saúde. 14 ed. São Paulo: Hucitec; 2014.

15. Fontanella BJB, Ricas J, Turato ER. Amostragem por saturação em pesquisas qualitativas em saúde: contribuições teóricas. Cad Saúde Pública [Internet]. 2008 [cited 2016 Dec 21];24(1)17-27. Available from: http://www.scielo.br/pdf/csp/v24n1/02.pdf

16. Bardin L. Análise de conteúdo. São Paulo: Edições 70; 2010.

17. Santos MA, Vieira EM. Recursos sociais para apoio às mulheres em situação de violência em Ribeirão Preto, SP, na perspectiva de informações-chave. Comun Saúde [Internet]. 2011 [cited 2016 Dec 11];15(36):93-108. Available from: http://www.scielo.br/ pdf/icse/v15n36/a08v1536.pdf

18. Osis MJD, Duarte GA, Faúndes A. Violence among female users of healthcare units: prevalence, perspective and conduct of managers and professionals. Rev Saúde Pública[Internet]. 2012 [cited 2016 Dec 15];46(2):1-8. Available from: http://www.scielo. br/pdf/rsp/v46n2/en_3137.pdf

19. Chibber KS, Krishnan S, Minkler M. Physician practices in response to intimate partner violence in southern India: insights from a qualitative study. J Women's Health[Internet]. 2011 [cited 2017 Apr 28];51(2):168-85. Available from: https://www.ncbi.nlm.nih. gov/pmc/articles/PMC3098281/pdf/nihms292345.pdf

20. Schraiber LB, D'Oliveira AFPL, Hanada H, Kiss L. Assistência a mulheres em situação de violência - da trama de serviços à rede intersetorial. Athenea Dig[Internet]. 2012 [cited 2016 Jan 11];12(3):237-54. Available from: http://atheneadigital.net/article/view/ v12-n3-schraiber-pires-hanada-etal/1110-pdf-pt

21. Menezes PRM, Lima IS, Correia CM, Souza SS, Erdmann AL, Gomes NP. Process of dealing with violence against women: intersectoral coordination and full attention. Saúde Soc[Internet]. 2014 [cited 2016 Dec 17];23(3):778-86. Available from: http:// www.scielo.br/pdf/sausoc/v23n3/en_0104-1290-sausoc-23-3-0778.pdf

22. Gomes NP, Bomfim ANA, Diniz NMF, Souza SS, Couto TM. Percepção dos profissionais da rede de serviços sobre o enfrentamento da violência contra a mulher. Rev Enferm UERJ[Internet]. 2012 [cited 2016 Nov 22];20(2):173-8. Available from: http://www.epublicacoes.uerj.br/index.php/enfermagemuerj/article/view/4035/2787 
23. Hasse M, Vieira EM. Como os profissionais de saúde atendem mulheres em situação de violência? uma análise triangulada de dados. Saúde Debate[Internet]. 2014 [cited 2017 Apr 29];38(102):482-93. Available from: http://www.scielo.br/pdf/sdeb/ v38n102/0103-1104-sdeb-38-102-0482.pdf

24. Sukhera J, Cerulli C, Gawinski BA, Morse D. Bridging prevention and health: exploring community perceptions of intimate partner violence in rural Honduras. J Fam Violence[Internet]. 2012 [cited 2016 Nov 26];27(7):707-14. Available from: https:// www.ncbi.nlm.nih.gov/pmc/articles/PMC3520440/pdf/nihms423408.pdf

25. García-Moreno C, Hegarty K, d'Oliveira AFL, Koziol-McLain J, Colombini M, Feder G. The health-systems response to violence against women. Lancet[Internet]. 2015 [cited 2016 Dec 04];385(9977):1567-79. Available from: http://www.thelancet.com/pdfs/ journals/lancet/PIIS0140-6736(14)61837-7.pdf

26. D'Oliveira AFPL, Schraiber LB, Hanada H, Durand J. Atenção integral à saúde de mulheres em situação de violência de gênero: uma alternativa para a atenção primária em saúde. Ciênc Saúde Colet [Internet]. 2009 [cited 2016 Dec 17];14(4):1037-50. Available from: http://www.scielo.br/pdf/csc/v14n4/a06v14n4.pdf

27. Lopes GVDO, Menezes TMO, Miranda AC, Araújo KL, Guimarães ELP. Acolhimento: quando o usuário bate à porta. Rev Bras Enferm[Internet]. 2014[cited 2016 Dec 17];67(1):104-10. Available from: http://www.scielo.br/pdf/reben/v67n1/0034-7167reben-67-01-0104.pdf

28. Parry S, Nascimento FS, Cordeiro R, Nanes G. Redes de Enfrentamento da Violência contra Mulheres no Sertão de Pernambuco. Estud Fems [Internet]. 2016 [cited 2016 Dec 11];24(3):851-70. Available from: http://www.scielo.br/pdf/ref/v24n3/1806-9584ref-24-03-00851.pdf 